\title{
Mandatory Social and Environmental Disclosure: A Performance Evaluation of Listed Nigerian Oil and Gas Companies Pre- and Post-Mandatory Disclosure Requirements
}

\author{
Mohammed Sani D. \\ Lecturer Centre for Entrepreneurship Development, Federal University, Dutse, Nigeria \\ Email address: \\ sdmshira86@yahoo.com \\ To cite this article: \\ Mohammed Sani D. Mandatory Social and Environmental Disclosure: A Performance Evaluation of Listed Nigerian Oil and Gas Companies \\ Pre- and Post-Mandatory Disclosure Requirements. Journal of Finance and Accounting. Vol. 6, No. 2, 2018, pp. 56-68. \\ doi: $10.11648 /$ j.jfa.20180602.12
}

Received: April 14, 2018; Accepted: May 2, 2018; Published: May 22, 2018

\begin{abstract}
Corporate social and environmental disclosure is still evolving and weak in developing countries and to stimulate the practice, many developing countries are putting in place regulations. Code of Corporate Governance for listed companies in Nigeria issued in 2011 mandated certain disclosure. Therefore, the main aim of this study is to assess volume of disclosure by listed Nigerian oil and gas companies six (6) years pre- and six (6) years post the code. Legitimacy theory is employed to underpin the study while corporate characteristics are tested to determine their influence on volume of the disclosure. Modified word count content analysis of annual reports and accounts of sample companies is used to determine volume of disclosure while two sample t-tests give the statistical mean of the disclosure. Panel Corrected Standard Error Regression analysis is used to determine the influence of corporate characteristics on the volume of the disclosure. Results from words counts content analysis indicated $53 \%$ increase in volume of social disclosure and $235 \%$ increase in volume of environmental disclosure six years post-code over disclosure six years pre-code. Two sample t-tests show that the mean of disclosure six years post code is greater than the mean of disclosure six years pre- code. Panel regression analysis results show that corporate size, have positive and significant relationship with disclosure. Obtained results is perhaps consistent with legitimacy theory.
\end{abstract}

Keywords: Mandatory Social and Environmental Disclosure, Nigerian Stock Exchange, Code of Corporate Governance

\section{Introduction}

In response to public demands for them to be more socially responsible, corporate organisations resorted to making voluntary social and environmental disclosure on their activities which is reported as increasing over the past decades [1]. Indeed, significant increase in global Social, Environmental and Governance (SEG) reporting in 2017 by surveyed $\mathrm{N} 100$ and $\mathrm{G} 260^{1}$ is attributed to regulations by governments and the stock markets [1]. Similarly, regulation may be the only driver to push the current stabilising increase in social reporting practices [1]. Therefore, although

1 N100 denotes the largest 100 studied companies by revenues in the 49 countries surveyed while G260 refers to the world's 260 largest companies by revenue based on the Fortune 600 ranking of 2016 [1] corporate social disclosure is acknowledged as voluntary [27]; mandatory requirements have arguably push the practice to current levels and could also play significant role in pushing the practices in the future [1]. Thus, despite reported advancement of the practice in developed countries, regulations abound in these countries. The Financial Service Reforms Act (FSRA) 2010 mandated social disclosures in Australia [8]. Similarly, Grenelle Act of 2009 in France provided for mandatory social and environmental disclosure [9]. Likewise, the United Kingdom (UK) revised companies' act 2006 mandated companies to make disclosure on social matters $[10,11]$. Equally, the largest companies in Denmark are required to make disclosure on climate and human rights in their annual reports and accounts [12]. Therefore, it is not surprising that governments and stock markets in developing countries are putting in place regulations to enhance social 
and environmental accountability. Listed and publicly owned companies in Indonesia are mandated to report on corporate social responsibility [12]. Also, the Securities Exchange Board (SEB) and Companies Act (AC) in India requires companies to report on corporate responsibility [12]. Similarly, the Johannesburg Stock Exchange (JSE) made it mandatory that companies should discuss the environment in which they are operating [13]. Thus, both developed and developing countries are putting in place mandatory requirements for corporate social disclosure to enhance the practice. Nigeria is a developing country and the Nigerian Securities and Exchange Commission (NSEC) recently mandated certain social and environmental disclosure in its Code of Corporate Governance (CCG) issued in 2011 [14]. Therefore, the main aim of this study is to assess volume of social and environmental disclosure by listed Nigerian oil and gas companies six (6) years before $(2005$ - 2010) and six (6) years after $(2011-2016)$ the issuance of the code. The objectives of the study are to assess the effectiveness of this government policy on disclosure by listed Nigerian oil and gas companies and to test the usefulness of legitimacy theory in explaining the disclosure. Therefore, the study proceeds thus; the next section which is the main body of the paper followed by results and discussion and conclusion sections.

\section{Literature Review}

In the field of accounting and finance, disclosure denotes the act of releasing all relevant information about a company that may influence the decision of investors $[15,16]$. Corporate social and environmental disclosure is conveying of information about activities of a company, its aspirations and the perception of the public on subjects dwelling on employees, community, and consumers. Reduced in these, are energy usage, fair trade, equal opportunities and corporate governance [17]. It is also seen as corporate provision of information on its interaction with community, employees, natural environment, environmental protection, resource use and the society at large [18]. Social and environmental disclosure are aspects of Corporate Social Responsibility (CSR); thus, the goals and benefits of CSR are invariably the same for social and environmental disclosure. The main goal for demanding CSR by early theorists and practitioners was how businesses could improve the society [19]. However, its overall objective is to enable businesses respond to other stakeholders' demand such as employees, customers, and the public on such topics as human rights, climate change and employee welfare [18]. Thus, under the CSR regime, businesses should be running their affairs taking into consideration all their stakeholders with a view to achieving sustainable development [20]. Achieving these and many other goals of CSR is beneficial to corporate organisations. It enhances corporate image, increase sales and market share, decrease operating costs, and increase corporate appeal to investors and financial analysts [21]. Corporate adoption of CSR also leads to lowering labour costs, allowing easy access to lenders and insurers, increases corporate reputation and increases market advantage of corporate organizations [22]. Despite these and other benefits of social and environmental disclosure, governments and stock markets globally are putting in place regulations demanding for mandatory disclosure.

The Australian government under its Financial Service Reforms Act (FSRA) of 2010 mandated financial services providers to disclose extent of consideration to labour, environmental, social and ethical issues in the selection, retention or realization of investments [8]. Similarly, the Grenelle Act of 2009 in France mandated all companies with more than 600 employees that initiated any polluting activity to report on air and water emissions, energy and materials usage; as well as firm's commitment to environmental protection, remediation and consequences on the natural environment while pursuing economic activities [9]. Similarly, The United Kingdom (UK) revised companies' act 2006, mandated listed and large non-listed companies to include in their business reviews information on social and environmental matters on with information on company's employees; social and community issues and impacts of company's business on the environment; $[10,11]$. The largest 1,100 companies in Denmark are required to make disclosure on climate and human rights in their annual reports and accounts [12]. These are some of the regulations from the context of developed countries portraying the significance of corporate social accountability. Many developing countries are also putting regulations demanding for mandatory social and environmental disclosure. The Johannesburg Stock Exchange (JSE) made it mandatory that companies should discuss the environment in which they are operating; their impacts on stakeholders and strategies put in place for mitigating potential negative impacts on the society in the form of an integrated report from 2011 [13]. The stock exchange in Malaysia (Bursa Malaysia) made ESG beginning from 31st December 2007 a listing requirement for all listed companies [13]. Likewise, listed and publicly owned companies in Indonesia are mandated to report on corporate responsibility in their annual report and accounts [13]. The Securities Exchange Board (SEB) and Companies Act (AC) in India requires companies to report on corporate responsibility in their annual reports and accounts [13]. Recently, the Nigerian Stock Exchange (NSE) issued a Code of Corporate Governance (CCG) for listed companies mandating disclosure on certain social and environmental issues [14]. Mandating social and environmental disclosure by developing countries is apparently proving useful as four out of the nine countries with CSR reporting higher than $90 \%$ in 2017 globally are developing countries of India, Malaysia, South Africa and Mexico [1]. There are debates on the influence of corporate characteristics as determinants of social and environmental disclosure.

\subsection{Corporate Characteristics and Disclosure}

In addition to making social and environmental disclosure mandatory, corporate characteristics are factors found influencing social disclosure by some studies while some 
studies reported them as not influencing the disclosure [23]. Thus, there are mixed results on the influence of corporate attributes on social disclosure and the debate is on-going. This study will contribute to the debate on effect of these corporate internal factors especially from the perspective of a developing country by exploring their effect on quantity of disclosure by sample companies.

\subsubsection{Corporate Size}

Corporate size is a variable that has been frequently used in studies on corporate social and environmental disclosure. Large firms are more geographically spread, therefore have larger market for products which may translate to having more diversified stakeholder groups thereby making such firms to disclose more information than small firms [24]. Similarly, large firms are more exposed to scrutiny from the public and social and environmental pressure groups than small firms, thus, are likely to make more disclosure [25]. Sales volume [26, 27], asset value [28], and number of employees [29] are used as proxies of corporate size. [27] reported significant correlation between corporate size and corporate social disclosure in the annual reports of Palestinian companies. Similarly, firm size is found statistically and positively related with volume of environmental disclosure by Dutch companies [29]. However, firm size is reported as non-significant in determining corporate social disclosure in Egypt [30]. Corporate size is also found not having statistical significance on social disclosure in a multinational study [31]. Thus, studies on impact of corporate size on social disclosure have revealed mixed results; therefore, below hypothesis is raised to test its effect in this study.

$\mathrm{H}_{1.0}$ : There is no relationship between quantity of social disclosure by sample companies and size

$\mathrm{H}_{1 . \mathrm{a}}$ : There is relationship between quantity of social disclosure by sample companies and size

\subsubsection{Profitability}

Corporate profitability is source of exposure to political pressure and public scrutiny; therefore, disclosure is used to reduce negative impact of these pressures [31]. Return on Asset [32]; Net profit [33] and Return on Equity [31] are used as measures of profitability; below are some findings. Strong positive association is reported between profitability and extent of social and environmental disclosure by Banks in Lebanon [34]. Likewise, level of social disclosure is found significant and positively related with profitability [35]. However, insignificant association between profitability and environmental disclosure levels is found in studied Thailand companies [36]. Similarly, [37] found no relationship between profitability and social disclosure levels of Spanish companies. Therefore, studies on effect of profitability as a determinant of social disclosure yielded mixed results; this study explore its effect on social disclosure by the sample companies by testing below hypothesis.

$\mathrm{H}_{2.0}$ : There is no relationship between quantity of social disclosure by sample companies and profitability.

$\mathrm{H}_{2 . \mathrm{a}}$ : There is relationship between quantity of social disclosure by sample companies and profitability.

\subsubsection{Leverage}

High leveraged firm implies the use of more debts in financing its operations than its own funds, while low leveraged firm means it is employing less of borrowed funds in its operations [38]. Corporate managers in leveraged companies are likely to increase disclosure to reduce agency costs between insiders and creditors. Therefore, leveraged companies are likely to make more social and environmental disclosure to satisfy creditors interested in social disclosure $[39,40]$. In contrast, highly leveraged companies are more likely to share information with their creditors, thus, making less disclosure [41]. Leverage is found having significant relationship with social and environmental disclosure practices of sampled firms in Bahrain [42]. Likewise, significant positive association between leverage and environmental disclosure quality is reported in studied Malaysian firms [43]. Conversely, [40] found no association between leverage and social disclosure. Equally, [44] found no statistical relationship between leverage and corporate environmental disclosure by sampled companies from Arab Middle East and North African Countries (MENA). This study will explore the effect of leverage on social and environmental disclosure practices of sample companies by testing below hypothesis.

$\mathrm{H}_{3.0}$ : There is no relationship between quantity of social disclosure by sample companies and leverage.

$\mathrm{H}_{3 . \mathrm{a}}$ : There is relationship between quantity of social disclosure by the sample companies and leverage.

\subsubsection{Liquidity}

Corporate liquidity depicts ability to meet current maturing obligations with short term assets [45]. Corporate organisations with high liquidity ratio will based on signalling theory make more disclosure than companies with low liquidity [46]. On the contrary, consistent with agency theory, companies with low liquidity will disclose more corporate information to satisfy the needs of shareholders and creditors [47]. Reference [33] found positive relationship between corporate liquidity and social and environmental disclosure by sampled Indian companies. Liquidity is also having positive relationship with corporate social disclosure by studied companies from Netherlands [48]. Contrariwise, [49] found no relationship between corporate liquidity and social disclosure by sampled Egyptian companies. This study employs this variable to explore its effects on the quantity of social disclosure by listed Nigerian oil and gas companies by testing below hypothesis.

$\mathrm{H}_{6.0}$ : There is no relationship between quantity of social disclosure by sample companies and liquidity ratio.

$\mathrm{H}_{6 . \mathrm{a}}$ : There is relationship between the quantity of social disclosure by sample companies and liquidity ratio.

Nigeria being the focus of this study; it might be useful here to look at social and environmental disclosure practices in the country in general and its oil and gas industry in particular 


\subsection{Social and Environmental Disclosure Practices in Nigeria}

Nigeria is a country located on the western coast of Africa bordered to the North by Republic of Niger; to the East by Chad and Cameroon; to the South by the Gulf of Guinea of the Atlantic Ocean; and to the west by Republic of Benin [50]. Reference [51] report that the country has 37.1 billion barrels of proved oil reserves as at December 2016. Similarly, the country has 186.60 trillion cubic feet of proved natural gas reserves at same period. Exploration and production of these natural resources are accompanied with lots of social and environmental impacts. For instance, exploring these resources entails converting scarce farming and fishing lands into oil fields which reduces food and cash crops production [52] thereby making people in the region poorer than other regions [53]. This poverty is the reason for massive rural -urban youth migration leading to over population in cities, increase in crime rates and pressure on scarce social amenities [54]. In communities where the youth endure, such social disorders as proliferation of arms, increasing illiteracy rate, lawlessness and destruction of local governance by emerging youth groups competing for scarce resources exist [55]. Benzene from gas flaring in the oil and gas producing region is the cause of such health problems as convulsions, chromosomal damage and birth defects [56]. Indeed, Nigeria's gas flaring is a global problem as the the country is among the top 20 most flaring countries [57]. Oil spillage $^{2}$ is another major environmental impact of the oil and gas industry in Nigeria $[58,59]$. Indeed, the problem of oil spillage in Nigeria is among the worst globally [60].

Nigeria is a country classified among developing countries [61] in which corporate social disclosure practices are reported as being at infancy stage $[62,63]$. This could be consistent with the argument that corporate organizations in developing countries are more concerned about how much profits are generated and how much dividends are paid, paying no attention to social and environmental issues and disclosure [64. Few available literatures suggest that corporate social disclosure is of significance to corporations in Nigeria. Social disclosure by banks in Nigeria are found useful by the banks in satisfying their stakeholders' interest [65]. Similarly, good corporate citizenship sequel to responsible corporate behavior encompassing social disclosure is an important component to achieving corporate economic mission [66]. The literature has also reported the nature of social disclosure by Nigerian companies. Information relating to products and consumers, employees and community involvement respectively, are the most disclosed items of corporate social disclosure by manufacturing companies [67]. Community involvement is found as the priority of Chief Executive Officers (CEO's) interviewed on corporate social disclosure, less priority on

2 Oil spill is simply defined as the accidental release of oil in the environment due to human activities which could be in water or on land. It is an aspect of environmental pollution with enormous environmental consequences (Odogwu, 2013). employees and none on socially responsible products and services [68]. Corporate characteristic of size and profitability are also tested in evaluating corporate social disclosure in Nigeria. Social disclosure by commercial banks is having positive relationship with size [69]. Return on Equity (ROE) as a proxy for profitability is found to have statistically positive relationship with corporate social disclosure [70]. There are also few existing social disclosure studies in the Nigerian oil and gas industry which is the focus of this study. There is lack of environmental accountability to stakeholders in the Nigerian petroleum industry attributed to weak government regulations; non-recognition of host communities as powerful stakeholders; and non-recognition of Nigerian public as legitimate stakeholders [71]. Consistent to this, listed Nigerian oil and gas companies are providing few words in their annual reports and accounts on social and environmental issues [72]. Gas Flaring Related (GFR) environmental performance and gas flaring related volumetric disclosure by dominant oil and gas companies in Nigeria are found statistically and positively related. Similarly, the companies are found making disclosure of hard GFR information to legitimise the production and flaring of Associated Natural Gas (ANG) in their operations [73]. Likewise, dominant oil and gas companies in the upstream sector of Nigerian oil and gas industry are making significant disclosure of gas flaring [74]. Reviewed literature has given an insight on social and environmental disclosure in general and Nigerian oil and gas industry. The focus of this study is on listed Nigerian oil and gas companies which are becoming important players from upstream to downstream sectors of the industry. Therefore, the study will give further understanding on recent disclosure practices of listed Nigeran oil and gas companies. In this way the study will contribute to knowledge on social disclosure practices in the oil and gas industry and the country in general. Social disclosure studies like this are normally underpinned by theoretical frameworks that assist in explaining corporate motivations for the disclosure; therefore, next section outlines some of the frameworks.

\subsection{Theoretical Frameworks in Social Disclosure Studies}

Political economy, stakeholder and legitimacy theories are among numerous theoretical frameworks used in explaining corporate motivations for social disclosure.

\subsubsection{Political Economy Theory}

Political economy is a subject matter consisting of the application of economic methodologies in the analysis of political behaviour and institutions [75] . It is also regarded as the social, political and economic frameworks in which human lives are taking place [76]. Corporate Social and Environmental Disclosures (CSED) from the perspective of this theory are reflections of the social, political, economic structures and power inequalities and conflicts surrounding the environment in which business operates [77, 78]. Thus, corporate reporting is a tool at the disposal of corporate managers to give their conceptions of the social, political and 
economic dimensions surrounding their operations [79]. Consequently, corporate social disclosure is all about constructing, sustaining, and legitimising economic and political arrangements that enhances corporate private interests [80]. Studies that found political economy theory useful in explaining corporate social and environmental disclosure among others include [81-82]. Stakeholder is another theory employed in the analysis of social disclosure.

\subsubsection{Stakeholder Theory}

Stakeholder is defined as "any group or individual that can affect or is affected by the achievement of an organisation's objectives" [85, p. 46]. This definition encompassing any group that can affect an organisation's achievement means firms have a stake in stakeholders' behaviour and are interested in the stakeholders for perceived benefits referred to as instrumental stakeholders [86]. The fundamental assumption of the instrumental stakeholder variant is that stakeholders are part of the business environment [87]. Therefore, an organisation identifies its key stakeholders then makes efforts to effectively manage them and corporate reporting is one means by which corporations could manage their stakeholders [88]. The other part of the definition by [85] stating that-stakeholders are affected by achievements of firms' objectives is denoted as normative stakeholder [89]. In this variant, managerial relationships with stakeholders are based on normative, moral commitments not for desiring profits [90]. Therefore, those stakeholders interested in social disclosure should be provided with the relevant information. In doing this, firms are discharging accountability to all its stakeholders which ought to be discharged [90]. Stakeholder theory is found useful in explaining corporate social disclosure [89, 90]; legitimacy theory is also used in underpinning social disclosure studies.

\subsubsection{Legitimacy Theory}

Legitimacy is defined as general perceptions that the actions of an entity are suitable, needed, or correct within the norms, values, definitions and beliefs of the society [91]. Therefore, the society allows corporate organisations to continue operations when they are meeting its expectations [92]. Thus, the society is the source of organisations legitimacy from the existence of an assumed social contract ${ }^{3}$ between the organisation and society [93]. Therefore, where an organisation is perceived as failing in its social contract, a legitimacy gap is said to arise [94]. In such instances the society can impose sanctions on the organisation in form of restricting its operations, limiting its access to resources and reducing demand for its products through boycotts [95]. Low legitimacy may even result in the forfeiture of an organisation's license to operate [96]. Consequently, it is important that an organisation ensure its continued legitimacy by identifying and managing its features [97]. First, ensuring that activities of the organisation agree with

3 This social contract is defined as "the multitude of implicit and explicit expectations that society has about how an organisation should conduct its operations" (Deegan, 2007a). societal expectations and perceptions; second, disclosing the activities of the organisation as agreeing with societal expectations [88]. Reference [97] identified four strategies that an organization may employ in gaining or maintaining legitimacy. First, the organization may make efforts to educate its 'relevant publics' about changes in its activities or performance by way of providing information to counteract or balance negative media news about the organization. Second, an organization may seek to change the perceptions of the relevant publics rather than change its actual performance by making available information about its previously unknown attributes to interested parties. Third, an organization may choose to contrive the perception of the relevant publics by swerving attention from the main issue of interest to related issues by way of appeal. The organization may for instance draw attention to environmental award won or implemented safety initiatives; downplaying its environmental pollution or workplace accidents. Fourth, an organization may seek to change the perceptions of its performance by the relevant publics. Organizations can employ social disclosure using each of the above strategies [97]. The theory is found useful in explaining corporate social and environmental disclosure.

A review of press articles by mining companies in South Africa suggest the use of pragmatic, moral and cognitive legitimacy to mitigate negative publicity [98]. Significant positive association between firm size and leverage and corporate environmental reporting by Malaysian companies provided support for legitimacy theory [43]. Social and environmental disclosure practices of companies in Bahrain are found better explained by Legitimacy theory [42]. Significant increase in the extent and quality of CSR disclosure found in studied Malaysian companies after the financial downturn and policy changes were to bridge legitimacy gap with the public [99]. Similarly, corporate social disclosure practices are reported significant and positively related with influence of external stakeholders such as foreign ownership and export oriented companies suggesting legitimacy efforts by corporate organisations in Bangladesh [100]. Carbon footprint intensive companies in Australia significantly increased their carbon reporting to gain legitimacy of their activities [101]. Progression in corporate social disclosure of studied companies in Mauritius is found to be strategically driven by efforts to assert legitimacy by the companies [102]. Equally, significant increase in environmental disclosure from an intra - industry environmental disclosure analysis of twenty-one out of twenty-six petroleum companies in the 1989 Fortune 600 were efforts to gain or maintain legitimacy [103]. Thus far, legitimacy theory has been found useful in explaining social and environmental disclosure in the literature. This study will add to the debate of the usefulness of this theory in explaining corporate social disclosure practices in an important sector of a developing country

\subsection{Data and Methods}

To have a clear understanding of the data and methods 
employed in conducting this study, it might be imperative to highlight on sample of the study. There are currently, nine (9) listed oil and gas companies on the Nigerian Stock Exchange (NSE) web site. However, one of the companies was listed in 2014. Therefore, there are no annual reports and accounts of this company for the period of the study 2005 to 2016. Accordingly, annual reports and accounts of eight (8) companies are collected and used in the study. Content analysis is employed to determine volume of disclosure six (6) years pre- and six years (6) post regulation.

\subsubsection{Content Analysis}

Content analysis is defined as a method in which qualitative data are converted to quantitative data systematically to aid analysis [104]. Similarly, the method is defined as a research technique that aid in making replicable and valid inferences from data and it assumes that extent of disclosure signifies the importance of the disclosed topic to reporting entity [105]. Reference [2] states that content analysis generally follows two paths of: one, number of disclosure and two, amounts of disclosure. To determine volume of disclosure, various units of measurement are employed in social disclosure studies. Word counts, sentence counts, average lines and proportion of pages [106, 26, 107, 2] are used and a researcher is free to choose the method considered most appropriate [108]. Number of words record disclosure levels in greater detail and is easier to be categorized [106]. However, word alone without sentence or sentences has no meaning to provide sound basis of coding social disclosure [74]. Therefore, sentence count is more appropriate being the conventional unit of speech and writing, and meaning can be discerned from sentences than words [26]. Nevertheless, it is criticized for possibility of ignoring differences in the use of grammar in that same message using similar words and space could be conveyed in different number of sentences [109]. Consequently, the most preferred unit of measurement is proportion of page as it reflects the total amount of space devoted to a topic, thus, portraying the importance of the topic to the reporting entity $[2,74]$. This method is also criticized as pages of annual reports and accounts may differ in terms of page, column and print sizes from one company to another [110]. This study adopts words counts content analysis based on its merits and the argument that a researcher is free to choose from the methods [108]. However, number of words in a phrase, sentence or page that is conveying meaningful social or environmental information are considered rather than individual words; thus, it is a modified word counts. In conducting content analysis, social disclosure studies develop disclosure index to help in identifying what is (not) social disclosure. This study adopts the Global Reporting Initiative (GRI) guideline being the most widely used corporate disclosure guideline to develop its disclosure index $[6,28$, $111,112]$. It could be noted that data for this study is for twelve (12) years divided into two equal parts and the number of companies are eight (8). Therefore, the data sets for the study are time series and cross sectional; thus, to explore the effects of corporate characteristics on disclosure, regression analysis as discussed next, is conducted.

\subsubsection{Time Series Cross Section Analysis (TSCSA)}

Time series data are characterized by having repeated observations, most often years on fixed units such as states and nations [113], but could also be on household or firm [114]. Thus, these data sets produce arrays of data that combine cross section data on $\mathrm{N}$ spatial unit and $\mathrm{T}$ time period to produce $\mathrm{N} x \mathrm{~T}$ observations. These types of data are posing some challenges to researchers when estimating suitable model for analysis. First, there is the tendency that errors in one unit $(i)$ at a period $(t)$ might be correlated with errors in unit $i$ at time $t+i$ referred to as serial correlation. Second, the errors might be correlated across the observations such that errors in unit $i$ at time $\mathrm{t}$ are correlated with errors in unit $j$ at time $t$; thus, there might be contemporaneous correlation. Third, there might be differing variance of errors in the observations such that units with higher values on variables may have higher variance on them or heteroskedasticity. Fourth, errors may contain both cross sectional and temporal effects, thus concealing unit and period effects. Fifth, errors may reflect some causal heterogeneity across space, time, or both since the process linking the dependent and independent variable tend to vary across sub sets of units or/and period [113]. These problems have ramifications in coming up with suitable estimable model for these kinds of data using Ordinary Least Square (OLS); hence, [113] developed the Generalised Least Square (GLS). However, GLS is also having problems of standard errors and to overcome this, [115] developed a method which retains the OLS parameters, but replaces its standard errors with Panel Corrected Standard Errors (PCSE's). Thus, in the case of homoscedasticity and contemporaneous independent errors, PCSE's performed as well as OLS where OLS errors are accurate $[115,116]$. When the performance of OLS decline due to less spherical errors, PCSE's still perform well, concluding that PCSE's errors should replace OLS standard errors for TSCS data [116]. PSCE's method of estimating a model for TSCS data sets is increasingly being used [73, 74, 117]. This study adopts the PCSE's method in estimating a suitable model towards answering raised research hypotheses in this study.

$$
\begin{aligned}
& Y=\beta_{0}+\beta_{1} S I Z E+\beta_{2} P R O F+\beta_{3} L E V+\beta_{4} L I Q+\varepsilon \\
& C S E D=\beta_{0}+\beta_{1} S I Z E+\beta_{2} P R O F+\beta_{3} L E V+\beta_{4} L I Q+\varepsilon
\end{aligned}
$$

Where:

CSED $=$ Quantity of social and environmental disclosures

$\beta_{0}=$ Slope of the intercept

$\mathrm{SIZE}=$ Corporate size measured by sales (turnover)

PROF $=$ Corporate profitability measured by earnings per share

$\mathrm{LEV}=$ Corporate leverage measured by total leverage LIQ $=$ Corporate liquidity measured by liquidity ratio and $\varepsilon=$ the error term 


\subsubsection{Two Sample T-Test}

Sometimes researchers are interested in looking at differences between two groups of samples. A two samples ttest is an inferential statistic that helps in analysing differences in the means of two samples drawn from two groups by comparing the means of the groups [118]. Therefore, this test is conducted to determine if there is statistically significant difference between the two groups based on their sample statistical means or the difference are by chance [119]. They are of two types paired/correlated and unpaired/uncorrelated t-tests. After assessing the normality of the data sets, its interval measurement, homogeneity of variance and independence of samples, a paired t-test is found most suitable to statistically determine the means of the two samples (pre- and post) regulation. Having had an outline of the data and methods employed in the study, the next section presents the results of the study.

\section{Results and Discussions}

One of the objectives of this study is to determine the volume of social disclosure by sample companies six years pre- and six years post regulation of certain aspects of social and environmental disclosure by NSE in 2011. Results obtained from modified word count content analysis is in Table 1 .

Table 1. Volumes of social words disclosures pre-and post-regulation.

\begin{tabular}{llllll}
\hline S/n & Pre-Regulation Years & Volume of social disclosures & S/n & Post-Regulation Years & Volume of social disclosures \\
\hline 1 & 2005 & 4,056 & 7 & 2011 & 13,127 \\
2 & 2006 & 5,296 & 8 & 2012 & 16,134 \\
3 & 2007 & 6,093 & 9 & 2013 & 18,950 \\
4 & 2008 & 10,111 & 10 & 2014 & 21,586 \\
5 & 2009 & 11,923 & 11 & 2015 & 25,806 \\
6 & 2010 & 12,463 & 12 & 2016 & 30,456 \\
Total & & 49,942 & & & 126,059 \\
\hline
\end{tabular}

Table 1 presents yearly and cumulative disclosure six years pre- and six years post regulation. Total disclosure words preregulation are 49,942 words while total disclosure postregulation are 126,059 words. Thus, there are increases of 76,437 words or $152.40 \%$ increase over total disclosure preregulation. Breaking the disclosure into social and environmental components indicates $53 \%$ increase in volume of social disclosure and $235 \%$ increase in volume of environmental disclosure post-regulation. Below Figures 1 and 2 is showing yearly trends of disclosure pre-and postregulation to enhance understanding.

\section{Social and environmental words pre-regulation (2005 - 2011) by Nigerian oil and gas companies}

14,000

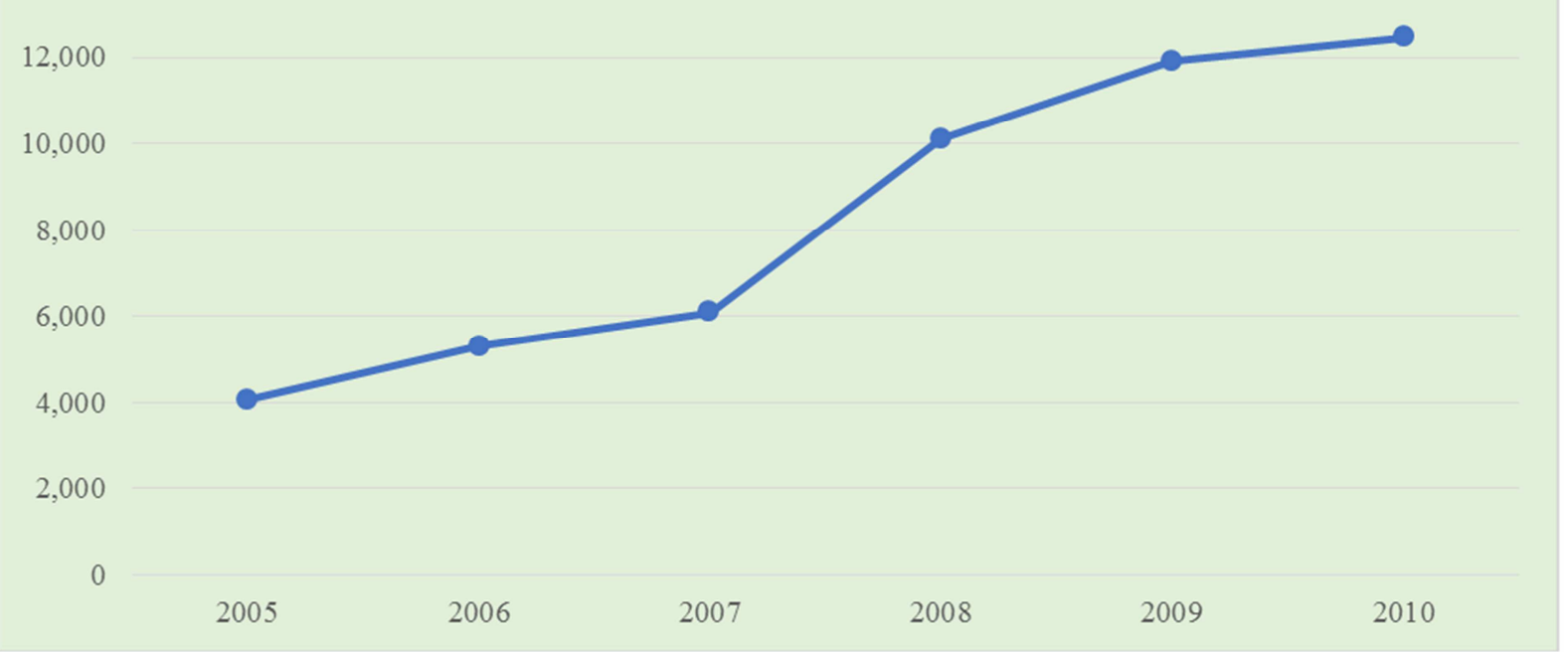

Figure 1. SED six years pre-regulation $2005-2010$. 


\section{Social and environmental words post-regulation (2011 - 2016) by listed Nigerian oil and gas companies}

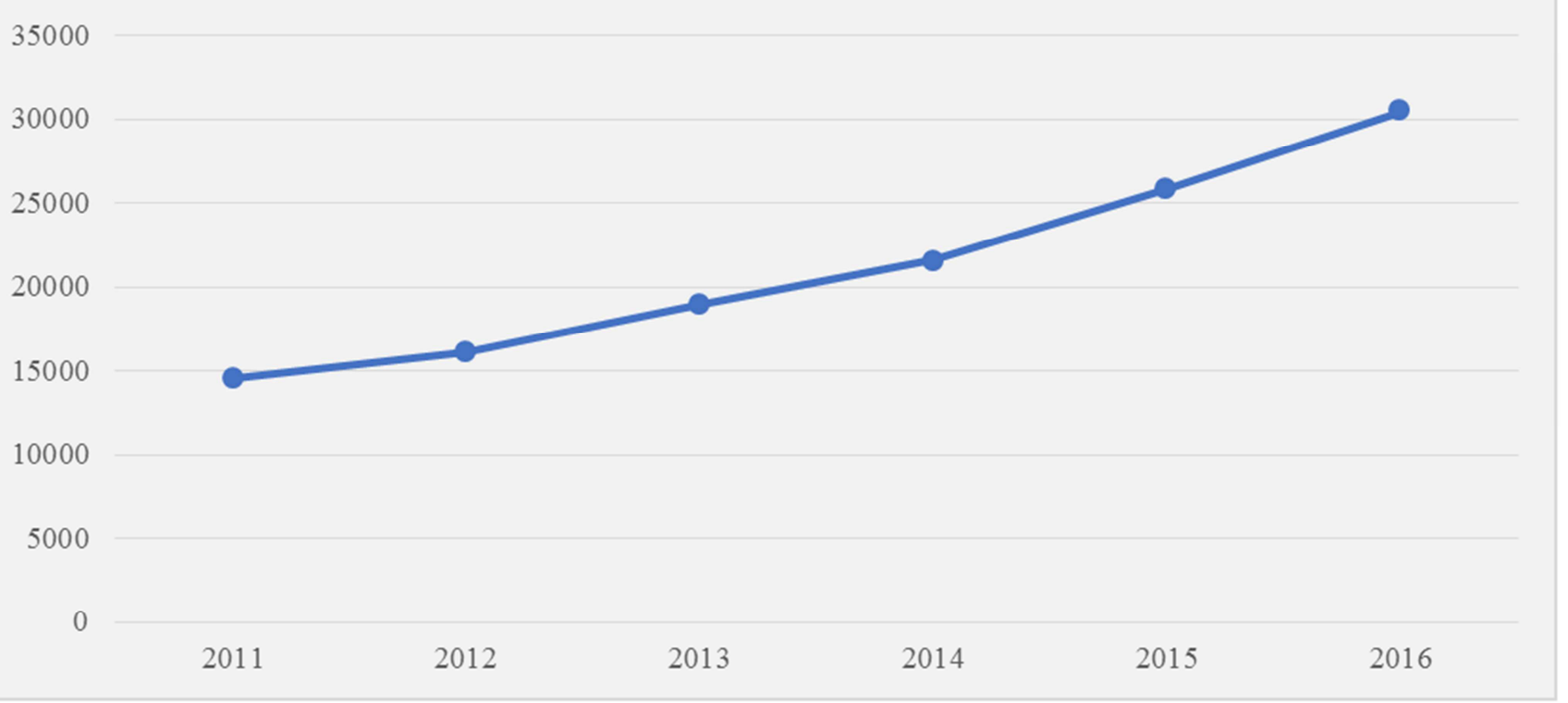

Figure 2. SED six years post-regulation 2011 - 2016.

Figure 1 depicts volume of disclosure six years preregulation in 2011 and the trend is showing increasing disclosure volume. Total of 4,056 words were disclosed in 2005 which increases to 5,296 words in 2006 representing $30.57 \%$ increase. Disclosure volume increased to 6,093 words in 2007 or $15.04 \%$ increase over disclosure volume in 2006 . The volume of disclosure increases to 10,111 words in 2008 representing 65.94\% increase over disclosure volume in 2007. Volume of disclosure in 2009 is 11,923 or $17.92 \%$ increase over 2008 disclosure volume. Total disclosed social and environmental words in 2010 are 12,463 words signifying $4.52 \%$ increase over 2009 disclosure volume. Figure 2 present disclosure volume post regulation $2011-2016$. The volume of disclosure in 2011 are 13,127 words equating 5.33\% increase in disclosure over disclosed volume in 2010. Total disclosed words in 2012 are 16,134 words; this is indicating $22.90 \%$ increase in disclosure volume over 2011. Total of 18,950 words are provided as social and environmental information in 2013 which is signifying $17.45 \%$ increase against disclosure volume in 2012. Disclosure volume further increased to 21,586 words in 2014, which is indicating $13.91 \%$ increase compared to disclosure volume in 2013. Volume of social and environmental disclosure further increased to 25,806 words in 2015 representing 19.54\% increase in comparison to disclosure volume in 2014. Total of 30,456 social and environmental words are disclosed in 2016, indicating $18.02 \%$ increase in disclosure volume compared to 2015. These are descriptive results of disclosure for the two periods; however, to present a more robust result, further statistical analysis in form of paired two sample t-test is conducted. If the mean of disclosure postregulation is higher than the mean pre-regulation, then, it confirms the descriptive result.
Table 2. Paired two samples t-test.

\begin{tabular}{llll}
\hline \multicolumn{2}{l}{ Paired samples t-test } & Hypothesis and result \\
\hline Variables & Obs & Mean & H0: variances between samples are \\
homogeneous H0: ratio =1)
\end{tabular}

Results in Table 2 indicate that the mean value of disclosure by sample companies' pre-regulation is 3.37 while the mean value of disclosure post-regulation is 3.81 . Thus, the mean of disclosure post-regulation is higher than the mean of disclosure pre-regulation by 0.44 . This statistical analysis is in conformity with results from quantitative words count content analysis. Results of regression analysis on the effects of size, profitability, leverage and liquidity on the quantity of social and environmental disclosure by sample companies are presented in Table 3.

Table 3. Results of Panel Corrected Standard Error Regression Analysis.

\begin{tabular}{|c|c|c|c|}
\hline \multicolumn{4}{|c|}{ Number of Obs $=96$} \\
\hline \multicolumn{4}{|c|}{ Number of groups $=8$} \\
\hline \multicolumn{4}{|c|}{ R-squared $=0.6212$} \\
\hline \multicolumn{4}{|c|}{ Wald chi2 $(6)=76.43$} \\
\hline \multicolumn{4}{|c|}{ Prob $>$ chi $2=0.0000$} \\
\hline \multirow{2}{*}{$\begin{array}{l}\text { LOG_CSED } \\
\text { Determinants }\end{array}$} & \multicolumn{3}{|c|}{ Panel-corrected } \\
\hline & COEF & Standard Error & P-value \\
\hline LOG_SIZE & .4769776 & .0997387 & 0.000 \\
\hline PROF & -.0000646 & .0001138 & 0.670 \\
\hline LEV & .1709989 & .4677067 & 0.716 \\
\hline LIQ & .00483 & .0069846 & 0.420 \\
\hline CONS & -4.882847 & 1.613864 & 0.001 \\
\hline
\end{tabular}

From Table 3 corporate size is the only variable found significant in explaining social disclosure by sample companies having a coefficient of.4769776 and p-value of 
0.000 which is significant at 0.05 percent. Varying the pvalue to 0.01 percent, size is still significant in determining volume of social and environmental disclosure. The result is consistent with findings by [27, 29]. Thus, corporate size which is exposing corporate organizations to political and public pressure is also playing a significant role on corporate social disclosure practices of sample Nigerian oil and gas companies. However, the result is inconsistent with [30] that found size insignificant in explaining social disclosure. The inconsistency could be attributed to differences in country contextual factors. Corporate characteristic of profitability is statistically found having no relationship with disclosure. This result is consistent with [36, 37], but inconsistent with $[34,35]$ that found profitability as significant in explaining disclosure. Corporate leverage is also found not significantly associated with social disclosure by sample companies. This result is consistent with [40, 44]; however, the result is not consistent with studies that found the variable significant in explaining disclosure [42, 43]. Corporate liquidity is also having no significant relationship with social disclosure. This is consistent with [49]; on the contrary it is not consistent with [33, 48]. On the overall, results from this study indicated (1) increased volume of disclosure post-regulation as obtained from the results of words count content analysis (2) there is statistical increase in mean of disclosure post regulation over disclosure mean pre-regulation; thus, confirming the descriptive result obtained from words count content analysis and (3) corporate size is having statistical significance in determining volume of social and environmental disclosure by the sample. It could be noted that the highest percentage increase in disclosure volume of $65.94 \%$ occurred in 2008 which was the year the code was speculated to come into force. Since then disclosure volume kept increasing and although the year in year out increase could be regarded as marginal, it is significant looking at disclosure volume pre-regulation. Disclosure volume in 2005 which is the first-year pre-regulation are 4,056 words, while disclosure volume in 2011 which is the first-year postregulation is 13,127 words. This is representing $223.64 \%$ increase over disclosure volume in 2005. Similarly, disclosure volume in 2006 which is the second-year preregulation is 5,296 words, corresponding to this is 2012 as the second-year post regulation and the disclosure volume is 16,134 words indicating 204.65\% increase over 2006. Likewise, disclosure volume in 2007 as the third-year preregulation is 6,093 words corresponding to this year postregulation, is the year 2013 in which disclosure is 18,950 words. This is signifying $211.01 \%$ increase in disclosure volume over disclosed volume in 2007 . In 2008, the fourthyear pre-regulation, total of 10,111 words are disclosed. Conversely, 21,586 words are provided in 2014 which is the corresponding year post-regulation; thus, giving $113.50 \%$ increase over disclosure volume in 2018. Total of 11,923 words are provided in 2009 as the fifth-year pre-regulation while 25,806 words are disclosed in 2015 being the corresponding fifth-year post-regulation. This gives $116.44 \%$ increase over disclosure volume in 2009. In 2010 the sixth- year pre-regulation, total disclosure volume is 12,463 ; however, disclosure volume in the sixth-year post-regulation is 30,456 words signifying $144.37 \%$ increase over disclosed volume in 2010 . Thus, in all post-regulation years, disclosure volume is more than twice disclosure volume in corresponding pre-regulation years. Therefore, it could be argued that the patterns of disclosure are meant to cement relationship with the regulator that mandated certain disclosure and this is perhaps better explained by legitimacy theory. Indeed, it may be in seeking to maintain legitimacy with NSE having powers to sanction listed companies that sample companies significantly increased their volume of disclosure beginning 2008 when the code was speculated to come into effect and kept increasing thereafter. Incidentally, regulated social disclosure are mainly on employees and host communities as legitimacy conferring stakeholders and to continue maintaining legitimacy with these, sample companies increased their volume of disclosure.

\section{Conclusion}

Social and environmental disclosure practices of listed Nigerian oil and gas companies is showing increasing patterns pre-regulation in 2011. However, the increase is more glaring post-regulation, perhaps to maintain legitimacy with the corporate regulator NSE. Increase in social disclosure is focusing mainly on employees and host communities which incidentally is also mandated probably also to maintain legitimacy with this legitimacy conferring stakeholders. Therefore, mandating certain aspects of social and environmental disclosure is found effective in ensuring social and environmental accountability by listed Nigerian oil and gas companies. This is evidenced by increased volume in disclosure on all mandated social and environmental aspects. However, the disclosure is not reflecting factual social issues such as providing alternatives to lost traditional sources of subsistence and income to solve the problem of poverty. Similarly, information is not provided on provision of medical and health facilities that could assist in overcoming health problems posed by oil and gas exploration and production. Similarly, information is not provided on environmental matters such as gas flaring and oil spill as reported in the literatures. Therefore, although mandating disclosure could be argued as useful based on increased disclosure in this study, government should device a means of ensuring that corporate organisations are reporting factual social and environmental issues occurring within their industry. Listed Nigerian oil and gas companies should aspire to be good corporate citizens by disclosing their social and environmental impacts and efforts to mitigate them. However, different result could be obtained if other disclosure indexes are used instead of Global Reporting Initiative (GRI) used in this study. Similarly, if other regression analyses other than PCSE methods are to be employed, different results could be obtained. 


\section{References}

[1] KPMG 2017. The KPMG Survey of Corporate Responsibility Reporting 2016, KPMG, The Netherlands.

[2] Gray, R., Kouhy, R. and Lavers, S. 1995b. Methodological themes Constructing a research database of social and environmental reporting by UK companies. Accounting, Auditing \& Accountability Journal. 8(2): pp.78-101.

[3] Tsang, E. W., 1998. A longitudinal study of corporate social reporting in Singapore: The case of the banking, food and beverages and hotel industries. Accounting, Auditing \& Accountability Journal, 11(6), pp.624-636.

[4] Clarke, J. and Gibson - Sweet, M., 1999. The use of corporate social disclosures in the management of reputation and legitimacy: a cross sectoral analysis of UK top 100 companies. Business Ethics: A European Review, 8(1), pp.6-13.

[5] Campbell, D., Craven, B. and Shrives, P., 2003. Voluntary social reporting in three FTSE sectors: a comment on perception and legitimacy. Accounting, Auditing \& Accountability Journal, 16(4), pp.668-681.

[6] Roca, L. and Searcy, C. 2012. An analysis of indicators disclosed in corporate sustainability reports. Journal of Cleaner Production. 20(1): pp.103-118.

[7] Alonso - Almeida, M., Llach, J. and Marimon, F., 2014. A closer look at the 'Global Reporting Initiative' sustainability reporting as a tool to implement environmental and social policies: A worldwide sector analysis. Corporate Social Responsibility and Environmental Management, 21(6), pp.318-336.

[8] Bollen, B., Skully, M. and Wei, X. 2010. The Financial Services Reform Act and Australian bank risk. Banks and Bank Systems. 5(1): pp.58-64.

[9] Doucin, M. 2013, The French legislation on extra-financial reportng: built on consensus, Ministry of Ecology, sustainable development and Energy, France

[10] UK Parliament. 2006. Companies Act. Act ed. UK: UK.

[11] Theron, C.2008. Environmental disclosures under the new Companies Act. UK: Environment Law. pp. 417 (5) a - c. Solicitor, Lawrence Graham, London.

[12] KPMG 2016, The KPMG Survey of Corporate Responsibility Reporting 2016, KPMG, The Netherlands.

[13] Ioannou, I. and Serafeim, G., 2014. The consequences of mandatory corporate sustainability reporting: evidence from four countries. Harvard Business School Research Working Paper, (11-100).

[14] NSE. 2011. Code of Corporate governance for public companies in Nigeria. Nigeria: Nigerian Stock Exchange. [Accessed 26 June 2014]

[15] Paul, E. et al. 2015. Financial statement presentation. UK: Pricewaterhouse Coopers. [Accessed 15 July 2016].

[16] Mahmud, S. and Islam, N. 2015. Compliance with Disclosure in Financial Audit: A Comparative Study of Some Selected Industries in Bangladesh. International Journal of Novel Research in Marketing Management and Economics. 2(1): pp.14-26.

[17] Gray, R. H. and Bebbington, K. J. 2001. Accounting for the environment. 2nd ed ed. London: Sage.

[18] Jenkins, H. and Yakovleva, N., 2006. Corporate social responsibility in the mining industry: Exploring trends in social and environmental disclosure. Journal of cleaner production, 14(3), pp.271-284.

[19] Carroll, A. B. and Shabana, K. M., 2010. The business case for corporate social responsibility: a review of concepts, research and practice. International Journal of Management Reviews, 12(1), pp.86-106.

[20] Glassman, J. K. 2006. Corporate Social Responsibility. American Review: pp.45.

[21] Kotler, P. and Lee, N. 2005. Corporate social responsibility. doing the most good for your company and your cause. Hoboken: John Wiley \& Sons.

[22] Azapagic, A. 2003. Systems Approach to corporate sustainability: A general management framework. Process, Safety and Environmental protection. Transactions of the Institution of Chemical Engineers. 81(5): pp.303-316.

[23] Adams, C. A. 2002. Internal organizational factors influencing corporate social and ethical reporting: Beyond current theorising. Accounting, Auditing \& Accountability Journal. 15(2): pp.223-250.

[24] Brammer, S. and Pavelin, S. 2008. Factors influencing the quality of corporate environmental disclosure. Business Strategy and the Environment. 17(2): pp.120-136.

[25] Ayadi, S. D. 2004. Determinants of the corporate decision to disclose stakeholders' reports in France. In: 27th Annual Congress of the European Accounting Association 2004. Prague: Czech Republic.

[26] Hackston, D. and Milne, M. J., 1996. Some determinants of social and environmental disclosures in New Zealand companies. Accounting, Auditing \& Accountability Journal, 9(1), pp.77-108.

[27] Alkababji, M. W. 2014. Voluntary disclosure on corporate social responsibility: a study on the annual reports of Palestinian Corporations. European Journal of Accounting Auditing and Finance Research. 2(4): pp.59-82.

[28] van de Burgwal, D. and Vieira, R. O. 2014. Environmental Disclosure Determinants in Dutch Listed Companies. USP, São Paulo. 25(64): pp.60-78.

[29] Tagesson, T. et al. 2009. What Explains the Extent and Content of Social and Environmental Disclosures on Corporate Websites: A Study of Social and Environmental Reporting in Swedish Listed Corporations. Corporate Social Responsibility and Environmental Management. 16(6): pp.352-364.

[30] Samaha, K. and Dahaway, K. 2011. An empirical analysis of corporate governance structure and voluntary disclosure in volatile capital market: The Egyptian Experiences International Journal of Accounting and Performance Evaluation. 7(1): pp.61-93.

[31] Prado-Lorenzo, J. M., Gallego-Álvarez, I., García-Sánchez, I. M. and Rodríguez-Domínguez, L., 2008. Social responsibility in Spain: practices and motivations in firms. Management Decision, 46(8), pp.1247-1271. 
[32] Luo, Y. \& Wu, D. H. 2010, "Shang shi gong si she hui ze ren bao gao ying xiang yin su yan jiu [Determinants of corporate social responsibility] vol. 169 p. $18-23$.

[33] Nandi, S. and Ghosh, S., 2013. Corporate governance attributes, firm characteristics and the level of corporate disclosure: Evidence from the Indian listed firms. Decision Science Letters, 2(1), pp.46-68.

[34] Menassa, E., 2010. Corporate social responsibility: An exploratory study of the quality and extent of social disclosures by Lebanese commercial banks. Journal of Applied Accounting Research, 11(1), pp.4-23.

[35] Chu, C. I., Chatterjee, B. and Brown, A. 2013. The current status of greenhouse gas reporting by Chinese companies' A test of legitimacy theory. Managerial Auditing Journal. 28(2): pp.114-139.

[36] Suttipun, M. and Stanton, P. 2012. Determinants of Environmental Disclosure in Thai Corporate Annual Reports. International Journal of Accounting and Financial Reporting. 2(1): pp.99-115.

[37] Echave, J. O. and Bhati, S. S., 2010. Determinants of social and environmental disclosures by Spanish Companies.

[38] Glancy, D. L. 2016, Opportunity in leveraged companies, Putman Investment, US.

[39] Alsaeed, K., 2006. The association between firm-specific characteristics and disclosure: The case of Saudi Arabia. Managerial Auditing Journal, 21(6), pp.476-496.

[40] Zhang, J. 2013, Determinants of Corporate Environmental and Social Disclosure in Chinese Listed Mining, Electricity and Chemical Companies Annual Reports, Edith Cowan University.

[41] Zarzeski, M. T., 1996. Spontaneous harmonization effects of culture and market forces on accounting disclosure practices. Accounting Horizons, 10(1), p.18.

[42] Juhmani, O., 2014. Determinants of Corporate Social and Environmental Disclosure on Websites: The Case of Bahrain. Universal Journal of Accounting and Finance, 2(4), pp.77-87.

[43] Sulaiman, M., Abdullah, N. \& Fatima, A. 2014, "Determinants of environmental reporting quality in Malaysia. International Journal of Economics, Management and Accounting, vol 22 no 1 pp. 63-90.

[44] Akrout, M. M. and Othman, H. B. 2013. A study of the determinants of corporate environmental disclosure in MENA emerging markets. Journal of Reviews on Global Economics. 2: pp.46-59.

[45] Poznanski, J., Sadownik, B. \& Gannitsos, I. 2013, Financial Ratio Analysis: A guide to useful ratios for understanding your social enterprise's financial performance.

[46] Abd-Elsalam, O. H., 1999. The introduction and application of international accounting standards to accounting disclosure regulations of a capital market in a developing country: The case of Egypt.

[47] Aly, D., Simon, J. and Hussainey, K., 2010. Determinants of corporate internet reporting: evidence from Egypt. Managerial Auditing Journal, 26(2), pp.182-202.

[48] Coebergh 2011.
[49] Hussainey, K., Elsayed, M. and Razik, M. A. 2011. Factors affecting corporate social responsibility disclosure in Egypt. Corporate Ownership and Control Journal. 8(4): pp.432-443.

[50] Falola, T. O. and Heaton, M. M. 2008. A history of Nigeria. 1 ed. United Kingdom: Cambridge University Press.

[51] BP 2017. BP (2017), "BP Statistical Review of World Energy 2017", available at https://www.bp.com/content/dam/bp/en/corporate/pdf/energyeconomics/statistical-review-2017/bp-statistical-review-ofworld-energy-2017-full-report.pdf (accessed 02 April 2018).

[52] Jike, V. T. 2004. Environmental Degradation, Social Disequilibrium, and the Dilemma of Sustainable Development in the Niger-Delta of Nigeria. Journal of Black Studies. 34(5): pp.686-701.

[53] Ebegbulem, J. C., Ekpe, D. and Adejumo, T. O. 2013. Oil Exploration and Poverty in the Niger Delta Region of Nigeria: A Critical Analysis. International Journal of Business and Social Science. 4(3): pp.279-287.

[54] Mabogunje, A. L. 1968. Urbanization in nigeria. London: University Press.

[55] Osuoka, A. and Roderick, P., 2005. Gas flaring in Nigeria: A human rights, environmental and economic monstrosity. 11672-UNI Nigeria. Amsterdam, Netherlands: friends of the Earth/International climate Justice Program. [Accessed 16 January, 2014].

[56] Tuodolo, F. 2009. Corporate Social Responsibility: Between Civil Society and the Oil Industry in the Developing World. An International E-Journal for Critical Geographies. 8(3): pp. 530-541.

[57] World Bank (2017), available at http://www.worldbank.org/en/programs/gasflaringreduction\#7 (accessed 27 April 2017).

[58] Benedict, A. O. 2011. Tragedy of Commons: Analysis of Oil Spillage, Gas Flaring and Sustainable Development of the Niger Delta of Nigeria. Journal of Sustainable Development. 4(2): pp.200-210.

[59] Allen, F. 2012. The Enemy Within: Oil in the Niger Delta. World Policy Journal. 29(4): pp.46-53.

[60] Ifeadi, N., Ekaluo, U. and Orubuma 1985. Treatment and disposal of drilling muds and cuttings in the Nigerian petroleum industry. In: International Seminar on the Petroleum Industry and Environment 1985. Nigeria: Nigerian National Petroleum Corporation.

[61] IMF 2016, World Economic Outlook, International Monetary Fund, USA.

[62] Dobers, P. and Halme, M. 2009b. Editorial Corporate Social Responsibility and Developing Countries. Corporate Social Responsibility and Environmental Management. 16: pp.237249.

[63] John, W. E., Daniel, C. E. and Angel, H., 2012. Environmental Performance Index and Pilot Trend Environmental Performance Index. USA: University of Yale Centre for Environmental Law and Policy. [Accessed 14 October 2013].

[64] Iyoha, F. O., 2010. Social accounting: An imperative for enterprise development. Nigerian Accountant, 43(1), pp.4-8. 
[65] Akano, A. Y. et al. 2013. Corporate Social Responsibility Activities Disclosure by Commercial Banks. In Nigeria. European Journal of Business and Management. 5(7): pp.173185.

[66] Effiong, S. A., Akpan, E. I. and Oti, P. A., 2012. Corporate Governance, Wealth Creation and Social Responsibility Accounting. Management Science and Engineering, 6(4), pp.110-114.

[67] Uwalomwa, U. and Jafaru, J. 2012b. Corporate Environmental Disclosures in the Nigerian Manufacturing Industry: A Study of Selected Firms. An International Multidisciplinary Journal, Ethiopia. 6(3): pp.71-83.

[68] Amaeshi, K. M. et al. 2006. Corporate social responsibility (CSR) in Nigeria: Western mimicry or indigenous practices? In: International Centre for Corporate Social Responsibility Nottingham University Business School Nottingham University 2006. UK: Business School, Nottingham University, pp.1-44.

[69] Akano, A. Y. et al. 2013. Corporate Social Responsibility Activities Disclosure by Commercial Banks. In Nigeria. European Journal of Business and Management. 5(7): pp.173185.

[70] Osazuwa, N. P., Okoye, F. A. and Izedonmi, F. 2013. Corporate Attributes and Environmental Disclosures of Nigerian Quoted Firms: An Empirical Analysis. Research Journal of Social Science and Management. 3(6): pp.150-158.

[71] Hassan, A. and Kouhy, R., 2016. From environmentalism to corporate environmental accountability in the Nigerian petroleum industry: do green stakeholders matter? International Journal of Energy Sector Management, 9(2).

[72] Mohammed, S. D. 2016. Social and Environmental Disclosures: A Comparative Analysis of Listed Nigerian and UK Oil and Gas Companies. PhD. Abertay University

[73] Hassan, A. and Kouhy, R., 2014. Evaluating gas-flaringrelated carbon emission performance in the Nigerian upstream sector: a comparison of duo methods. African Journal of Economic and Sustainable Development, 3(3), pp.264-27

[74] Hassan, A. 2012. Corporate Environmental Accountability in the Nigerian Oil and Gas Industry: The Case of Gas Flaring. $\mathrm{PhD}$. Abertay University.

[75] Weitzman, E. A. and Miles, M. B. 1995b. Computer programs for qualitative data analysis: A software sourcebook. USA: Thousand Oaks, CA: Sage

[76] Gray, R., Owen, D. and Adams, C., 1996. Accounting \& accountability: changes and challenges in corporate social and environmental reporting. Prentice Hall.

[77] Adams, C. A., Coutts, A. and Harte, G., 1996. Corporate equal opportunities (non-) disclosure. The British Accounting Review, 27(2), pp.87-108.

[78] Tilt, C. A., 1994. The influence of external pressure groups on corporate social disclosure: some empirical evidence. Accounting, Auditing \& Accountability Journal, 7(4), pp.4772 .

[79] Guthrie, J. E. and Parker, L. D. 1990. Corporate Social Disclosure Practice: A Comparative International Analysis. Advances in Public Interest Accounting. 3: pp.159-176.

[80] Tinker, T. and Neimark, M. 1987. The role of annual reports in gender and class contradictions at general motors. Accounting, Organizations and Society. 12(1): pp.71-88.

[81] Guthrie, J. E. and Parker, L. D. 1990. Corporate Social Disclosure Practice: A Comparative International Analysis. Advances in Public Interest Accounting. 3: pp.159-176.

[82] Gray, R., Kouhy, R. and Lavers, S. 1995a. Corporate social and environmental reporting: A review of the literature and a longitudinal study of UK disclosure. Accounting, Auditing \& Accountability Journal. 8(2): pp.47-77.

[83] Archel, P., Husillos, J., Larrinaga, C. and Spence, C., 2009. Social disclosure, legitimacy theory and the role of the state. Accounting, auditing \& accountability journal, 22(8), pp.1284-1307.

[84] Rosser, A. and Edwin, D. 2010. The politics of corporate social responsibility in Indonesia. The Pacific Review. 23(1): pp.1-22.

[85] Freeman, R. E. 1984, Strategic Management: A stakeholder Approach, 1st edn, Pitman, Boston.

[86] Friedman, A. L. and Miles, S. 2006. Stakeholders: Theory and practice. 1 ed. ed. UK: Oxford University Press.

[87] Berman, S. L. et al. 1999. Does Stakeholder Orientation Matter? The Relationship between Stakeholder Management Models and Firm Financial Performance. The Academy of Management Journal. 42(5): pp.488-506.

[88] Darsu, Mad and Yusoff, 2014

[89] Huang, C. L. and Kung, F. H., 2010. Drivers of environmental disclosure and stakeholder expectation: Evidence from Taiwan. Journal of Business Ethics, 96(3), pp.436-461.

[90] Roberts, R. W. 1992. Determinants of corporate social responsibility disclosure: an application of stakeholder theory. Accounting, Organizations and Society. 17(6): pp. 595-612.

[91] Suchman, M. C. 1995. Managing Legitimacy: Strategic and Institutional Approaches. Academy of Management Review. 20(3): pp. 571-610.

[92] Deegan, C. M. 2007. Financial accounting theory. 2nd ed ed. Australia: McGraw-Hill.

[93] Branco, M. C. and Rodrigues, L. L. 2006. Communication of corporate social responsibility by Portuguese banks: A legitimacy theory perspective. Corporate Communications: An International Journal. 11(3): pp.232-248.

[94] Donaldson, T. 1982. Corporations and morality. UK: Prentice Hall.

[95] Deegan, C. and Rankin, M. 1996. Do Australian Companies Report Environmental News Objectively? An Analysis of Environmental Disclosures by Firms Prosecuted Successfully by the Environmental Protection Authority. Accounting, Auditing \& Accountability Journal. 9(2): pp.50-67.

[96] Tilling, M. V. and Tilt, C. A. 2010. The edge of legitimacy Voluntary social and environmental reporting in Rothmans' 1956-1999 annual reports. Accounting, Auditing \& Accountability Journal. 23(1): pp.55-81.

[97] Lindblom, C. K. 1994. The implications of organizational legitimacy for corporate social performance and disclosure. In: Critical Perspectives on Accounting Conference 1994. New York, NY. 
[98] Loate, et al., 2017. Acid Mine Drainage in South Africa: A Test of Legitimacy Theory. Journal of Governance and Regulation 4(2):26-49.

[99] Haji, A. A. 2013. Corporate social responsibility disclosures over time: evidence from Malaysia. Managerial Auditing Journal. 28(7): pp.647-676.

[100] Khan, A. R., Muttakin, M. B. and Siddique, J. 2012. Corporate governance and corporate social responsibility disclosures: evidence from an emerging economy. Journal of Business Ethics. 114(2): pp.207-223.

[101] Hrasky, S. 2012. Carbon footprints and legitimation strategies: symbolism or action? Accounting, Auditing \& Accountability Journal. 25(1): pp.174-198.

[102] Mahadeo, J. D. and Oogarah-Hanuman, V. 2011a. A Longitudinal Study of Corporate Social Disclosures in a Developing Economy. Journal of Business Ethics. 104(4): pp.545-558.

[103] Patten, D. M. 1991. Exposure, Legitimacy and Social Disclosures. Journal of Accounting and Public Policy. 10(4): pp.297-308.

[104] Collis, J. and Hussey, R. 2014. Business research: A practical guide for undergraduate \& postgraduate students. 4th ed. UK: Basingstoke: Palgrave Macmillan.

[105] Krippendorff, K. 1980. Content analysis: An introduction to its methodology. Newbury Park: Sage Publications.

[106] Zeghal, D. and Ahmed, S. A. 1990. Comparison of Social Responsibility Information Disclosure Media Used by Canadian Firms. Accounting, Auditing \& Accountability Journal. 3(1): pp.38-53.

[107] Belal, A. and Lubinin, V. 2009. Russia: Corporate social disclosures. In: S. O. Idowu and W. L. Filho. eds. Global practices of corporate social responsibility. Germany: Springer-Verlag Berlin Heidelberg. pp.165-179.

[108] Williams, S. M. 1999. Voluntary environmental and social accounting disclosure practices in the Asia-pacific region: an international empirical test of political economy theory. The International Journal of Accounting. 34(2): pp.209-238.
[109] Unerman, J. 2000. Methodological Issues. Reflections on Quantification in Corporate Social Reporting Content Analysis. Accounting, Auditing \& Accountability Journal. 13(5): pp.667-680.

[110] Ng, L. W. 1985. Social responsibility disclosures of selected New Zealand companies for 1981, 1982 and 1983. Occasional Paper no. 54 Massey University, Palmerston North.

[111] Skouloudis, A., Evangelinos, K. and Kourmousis, F. 2009. Development of an Evaluation Methodology for Triple Bottom Line Reports Using International Standards on Reporting. Environmental Management. 44(2): pp.298-311.

[112] Lu, Y. and Abeysekera, I. 2014. Social and environmental disclosure by Chinese firms. 1 ed. UK: Routledge.

[113] Podestà, F.2002. Recent developments in quantitative comparative methodology: The case of pooled time series cross-section analysis. Decision Support System, Elsevier. (SOC 3-02): pp.1-44.

[114] Biorn, E. 2013. Introductory econometrics: on models and data types in econometrics. Available from: http://www.uio.no/studier/emner/sv/oekonomi/ECON4150/v1 3/undervisningsmateriale/econ3150_v12_note01.pdf

[115] Beck, N. and Katz, J. N. 1995. What to do (and not to do) with Time-Series Cross-Section Data. The American Political Science Review. 89(3): pp.634-647.

[116] Beck, N. and Katz, J. N. 2006. Random Coefficient Models for Time-Series-Cross-Section Data: Monte Carlo Experiments. Society for Political Methodology. pp.21 May, 2015-14.

[117] Barako, D. G., Hancock, P. and Izan, H. Y. 2006b. Factors Influencing Voluntary Corporate Disclosures by Kenyan Companies. Corporate Governance: An International Review. 14(2): pp.107-125.

[118] Healey, J. F. 2015. Statistics: A tool for social research. 10th ed. USA: Cengage Learning.

[119] Ha, R. R. and Ha, J. C. 2012. Integrative statistics for the social and behavioral sciences. USA: Thousand Oaks, Sage Publications. 